\title{
Some Highlights on the December Conference on Lu Xun and Devkota
}

\author{
Padma Prasad Devkota
}

https://doi.org/10.3126/litstud v29i01.39611

\begin{abstract}
From December 6-7, 2013, Devkota-Lu Xun Academy organized a two-day exhibition on "Lu Xun: Life and Works" in Kathmandu. The purpose of the event was apparently to bring peoples of China and Nepal together by seeking political and cultural connectivity in the writings of two literary giants, each of whom was born at a time of cultural and political transition of their respective nation into modernity. However, in reality, it sought to import and to establish Lu Xun (1881-1936) as an extreme leftist icon while identifying another such icon from within the nation itself. I intend to conceptualize some differences and similarities between these two poets mostly on the basis of the proceedings of the December Conference.
\end{abstract}

From December 6-7, 2013, Devkota-Lu Xun Academy organized a twoday exhibition on "Lu Xun: Life and Works" in Kathmandu. On the second day of the exhibition, Professor Gao Yangdong of Peking University, Professor Jon Eugene von Kowallis of the University of New South Wales, Australia, and Mr. Ninu Chapagain, a leftist critic presented papers on Lu Xun (1881-1936). The much expected scholar from Renmin University of China, Professor Sun Yi, could not come, but his very perceptive paper on "The Heritage of Lu Xun and Dostoyevsky" did arrive. Only Dr. Ram Prasad Gyawali, a poet and leftist critic, presented a paper on Laxmi Prasad Devkota (1909-1959). The purpose of the event was apparently to bring peoples of China and Nepal together by seeking political and cultural connectivity in the writings of two literary giants, each of whom was born at a time of cultural and political transition of their respective nation into modernity. Since what came out of the conference was what was put so diligently by each scholar into his paper, I would like to begin by giving a brief account of the impression each paper left in my mind. The conference highlighted several important facets of Lu Xun and Devkota which I would like to discuss in this paper.

Professor Gao Yangdong's "Cultural Features Based on the Consciousness of Confession-An Analysis of $\mathrm{Lu}$ Xun's Enlightenment Discourse" deals with the cultural and literary aspects of Lu Xun. The very opening phrase-_"Lu Xun's cultural enlightenment thoughts" (1)—suggests a Chinese Enlightenment as opposed to Enlightenment in Europe of the eighteenth century. While Enlightenment in the West worshipped at the altar of Rationality, it is difficult for me to say at this point in time whether Chinese Enlightenment means anything radically different or lasting outside the life-span of its pioneers: Liang Qichao, Lu Xun and Zhou Zuoren. If it does, it has to do also with the introduction of Western science and democracy (5) into a nation devastated by centuries of slavery to the "cannibalism" of a ruling class. It was against such slavish mentality inside China and against threats of Western culture from outside that $\mathrm{Lu}$ Xun wanted to guard his nation. If he writes the cultural history 
of slavery in China in "The Story of Ah Q," Gao Yangdong claims that Lu Xun "thinks that in some sense the introduction of 'science' and 'democracy' to China from foreign cultures can be helpful for redemption and treatment for the underdeveloped China" (5). Western science had at least "served as a catalyst in the Meiji era (1867-1912) reforms in Japan" (Jon Kowallis Lyrical Lu Xun 14) and Lu Xun was hopeful it would do so in China too.

Highlighting Lu Xun's honesty and sincerity as a writer, Professor Gao finds two voices at work in his writing: that of the narration of enlightenment and that of critical questioning of the enlightenment discourse (6). What is striking about this two-fold voice is that it speaks of Lu Xun's quest for a strong national identity. While he wishes to welcome the "instrumental rationality" (6) of the West to cure uncritical habits at home, he remains cautious lest it overtake national interests and cultural cause. To fend off such evil, Lu Xun seems to do two things: first, as Gao Yandong says, "he looks into the whole world and human nature from the perspective of an oppressed nation and he provides the human society with introspective experiences" (7) and, second, apparently under the influence of a rich cultural tradition founded on Confucianism, Taoism and Buddhism, especially the last, he looks at the impermanence of everything including Enlightenment and expresses "great doubts about enlightenment discourse" (6). If the first indicates his national and human concern, the second suggests a transcendental tilt, which I regard as an essential element of great poetry. Lu Xun also transcends the uncritical masses by virtue of his critical competence. As a nationalist, his "consciousness of repentance" is explained by the tradition of slavery from which the Chinese would have to emancipate themselves through rational and critical thinking. As Professor Sun Yi tells us, in his essays Lu Xun "touched on the horror of being enslaved" ("The Heritage" 6). Thus, if science and democracy were instrumentally necessary for China, it had still to be wary of falling from the pan into the fire, of being subjected to slavery of Western Culture. The spirit of struggle against such forms of slavery defines Chinese modernism, says Professor Gao. However, for Lu Xun, modernization of China alone would remain insufficient: "Man cannot live by bread alone" need not be understood as a Christian dictum only. For Lu Xun, Chinese life was absurd and he needed to struggle against despair knowing that he was just one finite mortal doing the best he could. His strength grew with continued critical questionings and he became more and more concerned with universal human beings.

What especially strikes me in Gao Yangdong's paper is the way he explains Chinese modernism.

The process of desperate struggle and resistance is also the process of free spiritual advancement for liberation of Asian subjectivity from the slavery of western culture. The literature which started to have such spirit of desperate struggles and resistance can be regarded as the starting point of Chinese modern literature. The writer of the paper believes the motivation of such struggle and resistance originates from the dialectical enlightenment way of thinking. (4)

Thus "dialectical enlightenment" with its emphasis on synthesized knowledge defines and demarcates Chinese Enlightenment from European 
Enlightenment to some extent. Of course, one can always ask how a claim to being scientific might differ from the practice of science. I for one have refused to discard intuition as a source of knowledge and see such intuitive magicmoments behind not only Confucianism and Buddhism but also many scientific inventions and discoveries. But that is beside the point. Chinese literary modernity has the added element of resistance against slavish submission to western culture, that is, uncritical acceptance of foreign influences. This, I believe, is what goes to form and define a modern Chinese experience because no state building is possible without a solid foundation of a strong cultural past.

The next paper by Jon Eugene von Kowallis, "Issues in Translating and Interpreting Lu Xun's Classical-Style Poetry," is apparently motivated by a need to justify academic scholarship against political academics that seeks to resurrect "Nationalist China." He defends himself against Wu Jun's accusation that foreigners translate literally because they do not understand Chinese culture like the Chinese nationals do. "I take exception to Wu Jun's conclusion, says Kowallis, "when she writes: 'In the final analysis it is much easier for us Chinese to understand and translate Lu Xun's poetry than for foreign scholars"” (8). To understand, probably yes; to translate, probably no! Academic scholarship shuns such sweeping generalizations, which are characteristic of political academics by which I mean academic writing with a political agenda. In this case, it is one of identity: nationals vs. foreigners. I think this quarrel needs to centre on competence. If it does so, it will be obvious that we are all incompetent translators either because we lack a proper understanding of the source language and its culture or a proper mastery of the target language and its culture. We must give $\mathrm{Wu}$ Jun the benefit of doubt since there have been instances of bad translations of culture by foreigners. However, many nationals are no better than foreigners when it comes to translation because of their lack of understanding of how the modern idiom of the target language plays an important role in the communication of ideas. We can generally accept that good translation conveys the original meaning as accurately as possible, expresses this meaning in a suitable language, and is readable in the receptor language.

At this point, I would like to digress a little into my own experience of

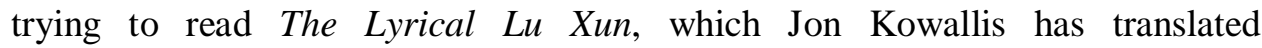
painstakingly for the native Anglophone world. At first, I tried reading the poems without the help of the introductions and the footnotes; but nothing seemed to make sense at all. Proper names were strange and difficult to pronounce. "A Jiangsu doll," "The Xiang goddess," "the Realm of Yu," or even "Qiuanmen Station" were all unfamiliar things and places that were blank spots of the texts in which they occurred. When I came across two lines that seemed to make sense, I underlined them:

Writings worth their weight in dirt, wither can one go? (191)

Some poems such as the one beginning with "My soul takes wing so oft in dream" (84) were simple because they expressed general human sentiments. The pseudo internal rime in the verse above caught my attention at once. In this poem, I even appreciated the agricultural imagery of the wick's flame being 
"bean-sized" (84). One does not have to understand everything in a poem to enjoy it. I found "An Offertory for the God of Books" compatible with my temperament. However, the seventh "Untitled" poem in this volume made no sense to me at all until after I had read both the introduction and the footnotes although such footnotes are "increasingly challenged in the post-modern era by those who say they want to produce translations "unencumbered by footnotes" ("Issues in Translating" (6). Postmodernism need not dictate my taste for poetry or how it is served to me. Now, whether lingtai means Spirit Tower or not is for scholars like Kowallis and Wu Jun to debate. As a reader of Lu Xun, the tenth note which reads "lingtai...is used to refer to the mind or the heart in its function as the seat of the intellect" (104) makes sense to me and opens up a vista of plausible interpretation of the poem. What I am driving at is simply that, in the absence of a monolithic truth, an interpretation of a text that is intellectually satisfying has to suffice. And translation, too, is an act of interpretation of the original text. For as long as it does not run away like a beautiful bride, it can remain wedded to scholarship. I never thought of Edward FritzGerald's rendering of Omar Khayyam's Rubaiyat as bad poetry on account of its supposed inaccuracies. It has always delighted me.

Kowallis, however, has given translation much serious thought and clearly outlines his translation concepts: "We want to bring across the power of the original by transferal of imagery from one language to another," he says. To do so, "You may need to change some of the wording, but you want to hold onto the original images. While the problems of interpretation exist, people of the post-modern era want translations "unencumbered by footnotes," (6) he writes. However, footnotes are all too essential for the likes of me. From examples provided in the text, it appears to me that Jon Kowallis transcreates portions of the Chinese original text to enrich the metaphors in his translation and this act is regarded as lack of cultural understanding by some politically motivated native critics. This is painful to the translator who hits back by explaining what translation means to Wu Jun: yi ji yi, to translate means precisely to change. The punch lies exactly here.

Ninu Chapagain's "Lu Xun in the Context of Nepal," the third paper ${ }^{1}$ presented in the Conference, is well-aimed at a select audience. It does a good job of introducing Lu Xun, first, by tracing the appearance and reception of $\mathrm{Lu}$ Xun in Nepal through biography, introductory articles and translations. Next, Chapagain goes on to describe the present historical context of Nepal, that is, the change of regime from monarchy to republic, which provides an optimized climate for the reception of $\mathrm{Lu}$ Xun's thoughts: “... we are receiving revolutionary zeal, motivation, energy and self-confidence from Lu Xun literature"(4). And, this revolutionary zeal is directed towards a cultural transformation in Nepal through the displacement of superstition by science. Chapagain writes, "If we want to learn from Lu Xun's writing, we have to pay attention to two things. First, it is necessary for a writer to become a student and researcher of life and society; second, one has to be able to use writing as a means of struggle for justice" (12). He also explains that the term "people's literature" does not mean the same thing for Nepalese writers and for Lu Xun.

\footnotetext{
${ }^{1}$ All English renderings of the citations from this and the next paper are my own.
} 
For these writers, it means literature which is written on behalf of the people; for $\mathrm{Lu}$ Xun, it is literature written by the people only after the revolution is over (15).

In this way, Chapagain finds in $\mathrm{Lu}$ Xun ideas and guidelines for revolutionaries in Nepal. For him, the literariness of a Lu Xun text depends on its power of social and cultural reform. No one denies that justice is the demand of the whole human world. However, it does not follow that all critical questioning is "Progressive" because this is what the "progressivists" want to do. It is true that we all need to learn from great writers. However, if, as Chapagain claims, reformation is synonymous with revolution for Lu Xun too (6), we beg to differ with both the Chinese Poet and his Nepali fan. The word "revolution" itself has undergone several changes in meaning throughout history and what was at first understood as a swift and sudden turn of (political) event such as a change of regime has now become a gradually erosive force of progressive ideology. But, a revolution that takes too long to happen loses its force and people stop believing in it. Had Mr. Chapagain approached Lu Xun as a conscientious literary critic, he would have avoided trying to suggest that we should choose science over superstition because Lu Xun believes this is the right thing to do (1-4). Of course, it is the right thing to do, but with judgment. Leaving aside Lu Xun's Marxist connections for the present, we have to remember that science has changed radically since the time of Karl Marx. Yet, the changes brought about in our lives by science may not have contributed to the well-being of human societies. Progress as science and technology begs the question. Lu Xun's power as a great poet, writer and thinker, I believe, certainly does not rest in mere progressive ideology with a politic path to tread. He is without any doubt a world-class poet like Devkota.

In "Gradually Progressive Mahakavi Devkota," Dr. Ramprasad Gyawali, another "progressive" critic, claims that Devkota developed through the stages of Idealism and Romanticism to that of Progressive Thought and Progressivist Literature. The terms "progressive" and "progressivist" are ill-defined and sound synonymous. The overall impression of Devkota from this paper is that he believed in the Marxist idea of progress as a vital journey towards an end-this end being the ultimate emancipation of suppressed human potentials. The paper does not mention the other Marxist end - control of natural environment. Instead, several occurrences of affective language and Marxist jargons indicate a political motive of the writer who, nevertheless, agrees with Balakrishna Sama, the poet's contemporary playwright, that Devkota is more than the sum total of his works. Although I know that Dr. Gyawali considers Devkota as one of the best poets of Nepal, it is also true that he greatly undermines the poet by labeling him a "nearprogressivist."

Respectively, each of the two Nepalese scholars read Lux Xun and Devkota as progressivists, leaving us with a sense of insufficient literary justice being done to both the writers. As with the preceding paper, the problem with this one too is that instead of paying attention to a proper use of Marxist critical methodology to analyze literature, it seeks to isolate instances of Devkota voicing against injustice in a feudal world. Such populist political emphasis in literary criticism is plainly discomforting because it impinges upon literary territory and attempts to remap it from within so that appreciation of good poetry is dictated by practical reformative results in the real world as if poetry 
did not have a spiritual dimension. Not that it is wrong to read literature from a political perspective, but one wonders which honest writer has not spoken up against injustice. Let us take an example of Devkota's verse that Dr. Gyawali has cited in his text (6).

Snatch from the landlord this lordship of the earth,

Become the globe itself, farmers, to speak in a single voice.

Legions of the poor on one side, the rich on the other,

with staff in your hands, farmers, scare them only!

If you do not falter, the deceitful will cower down.

(My translation with emphasis added.)

There is little doubt that the poet here is rousing suppressed farmers to stand up against exploitation and to fight for their rights. However, Devkota's injunction is not to kill but to "scare them only!" This is very similar to the initial attitude of the revolutionaries against the gentry after the 1911 Manchu Revolution: they did not want to beat dogs that had fallen into the water. This shows a certain nobility and compassion on the part of the Chinese revolutionaries of that period which, for instance, their counterparts of the French Revolution did not possess. This is also what marks the difference between a guerrilla warrior and a compassionate poet. One is moved by anger and revenge, the other by love and kindness. For Dr. Gyawali, poetry in the above cited lines seems to lie in the call to unite and fight, not in the compassion. He does not even notice it. Yet, Devkota is a poet for whom love is at the centre of everything. Throughout his life, Devkota found beauty in what promoted life, security and happiness of the living. To him, violence is ugly:

The soul of man, if violence were the law,

Would man destroy and his whole great race kill,

And the brute power, the tooth and claw,

Kill not violence, but his race blood spill. ${ }^{2}$

(Bapu Sonnet xvi)

Probably he would not have disagreed with $\mathrm{Lu}$ Xun in that a dog that bites a human being should be beaten whether it has fallen into the water or not (Chapagain 6). However, poets of this stature do not seek to kill these dogs.

Here, I would momentarily like to turn to Sun Yi's paper, "The Heritage of Lu Xun and Dostoyevsky," even though it was only meant to be presented at the conference. Discussing the balance between $\mathrm{Lu}$ Xun's "reverence for scientific rationality" (3) and his "aesthetic judgment" (3), Sun Yi makes a very astute observation: "Even at those moments of turning leftist, Lu Xun managed to maintain his vigilance against rigid dogmas" (3). Fanaticism and dogmatism are the two of greatest sins of mankind whether they appear in religion, politics or culture. Like Devkota, Lu Xun also seems to have lived more in his heart than in his head for sensory experience meant a great deal to him, although this did not mean allowing the brain to rust. All sense perception was filtered through the heart before it reached the brain in the case of Devkota whose moral conscience never wilted till the end of his days. Talking of Lu Xun, Sun Yi observes:

The indifference and barriers characterize human communication and people take for granted hurting one another. Very painfully, Lu Xun pointed out that those cases represent the

\footnotetext{
${ }^{2}$ Poet Devkota wrote this originally in English.
} 
very irrationality of human existence and it is truly a great difficulty for human beings to be freed from such miserable conditions. (5)

Today we not only relish news of rape, abuse, torture, murders and even accidents, we also take all these for granted, thanks to the daily tabloids which would not sell without such news. Yet, far beyond our modern attraction to evil, there is deep within each human heart a sense of the sublime-either the absence of cruelty and benevolence in the innermost recesses of our soul as Sun Yi says (2) or a sort of a fusion of the Good and the diabolically Evil in a Zizekian sense - which Lu Xun discovered in Dostoevsky's writing and found out that "the author was a spiritual traitor" (Sun Yi 2). "All the confines imposed by the traditions were disrupted, revealing a new figure dancing on the highlands of spirituality" (2). In his own case, perhaps Lu Xun experienced the abject in the context of the "emptiness of enlightenment" (8) as Gao Yandong puts it. Struggling against hope, he was a brave man. For Devkota, there was something even more than a Zizekian sublime to fall back upon: human will had at least a choice between the Good and the "diabolical" Evil. It chose the True, the Beautiful and the ever Delightful and called it "the Good." I understand that $\mathrm{Lu}$ Xun did not share Devkota's faith "in the existence of a human spirit, a nonmaterial inner personality embodied in the physical frame" (MSS.). Yet, this is exactly the difference that draws us closer to one another out of mere curiosity. We would like to see more of such aesthetic connectivity between writers of China and Nepal.

\section{Works Cited}

Chapagain, Ninu. "Lu Xun in the Context of Nepal. ("नेपालकासन्दर्भमा लुसुन ।") Paper presented at the Devkota-Lu Xun Conference in Kathmandu, December 2013.

Devkota, Laxmi Prasad. Bapu and Other Sonnets. Kathmandu: Mahakavi Laxmi Prasad Devkota Study and Research Centre, 2006.

---. "The Philosophy of Silence and Inaction." ms. Personal collection.

Gyawali, Ramprasad. "Gradually Progressive Mahakavi Devkota.” (æqmdzM k|ultzLn dxfslj b]jsf]6f .Æ) Paper presented at the Devkota-Lu Xun Conference in Kathmandu, December 2013.

Kowallis, Jon Eugene von. "Issues in Translating and Interpreting Lu Xun's Classical-style Poetry." Paper presented at the Devkota-Lu Xun Conference in Kathmandu, December 2013.

---. The Lyrical Lu Xun: A Study of His Classical-Style Verse. Honolulu: University of Hawai'i Press, 1996.

Yangdong, Gao. "Cultural Features Based on the Consciousness of ConfessionAn Analysis of Lu Xun's Enlightenment Discourse." Paper presented at the Devkota-Lu Xun Conference in Kathmandu, December 2013.

Yi, Sun. "The Heritage of Lu Xun and Dostoyevsky." Paper written for the Devkota-Lu Xun Conference in Kathmandu, December 2013. 